\title{
Effectiveness of E-learning Mode for Teaching English Language in Arab Universities
}

\author{
Bilal Mohd Zakarneh*
}

College of Mass Communication and Humanities, Ajman University, UAE

Corresponding Author: Bilal Mohd Zakarneh, E-mail: zakarny@hotmail.com

\section{ARTICLE INFO}

Article history

Received: July 20, 2018

Accepted: September 26, 2018

Published: December 01, 2018

Volume: 7 Issue: 7

Advance access: October 2018

Special Issue on Language \&

Literature

Conflicts of interest: None

Funding: None

\begin{abstract}
E-learning is increasingly being embraced by the traditional academic institutions, hybrid educational organizations and newly established online organizations for teaching English and other subjects in universities in the Arab world. The present study investigated the effectiveness of using e-learning platform to teach the English language to students in Arab universities. Data was collected using a questionnaire and analysed using excel data analysis tool. Results revealed that e-learning platform is an effective platform for teaching English language. Participants held that they learned better via e-learning and that all English language courses should be taught through the e-learning mode. They consider e-learning platform as appropriate and better means for acquiring vocabulary, developing speaking skills, English language grammar, reading skills, writing skills, listening skills, and as a better mode of enhancing performance in English than the traditional classroom mode. They see e-learning as a better tool for testing and evaluation and prefer it to other traditional methods. Conclusion: e-learning can be more effective in learning English than the face-to-face classroom system.
\end{abstract}

Key words: E-Learning, Blended learning, E-Learning Tools, Web-based Tools, Traditional classroom System.

\section{INTRODUCTION}

E-learning is increasingly being embraced by the traditional academic institutions, hybrid educational organizations and newly established online organizations for teaching English and other subjects in universities in the Arab world. This has been acknowledged by Al-Shehri (2010) that different universities in the Arab countries have accepted and implemented the e-learning concept and achieved considerable levels of success. According to Ghaffari and Abbas (2011), the increased adoption of e-learning platforms in Arab universities is aimed at expanding distance learning. The increased adoption of e-learning is also based on results of several studies that demonstrated the value of e-learning relative to the traditional classroom based-learning as demonstrated herein. Surprisingly, results of studies on the value of e-learning relative to the traditional classroom based-learning or the effectiveness of e-learning platform has been questioned largely because some studies have affirmed its effectiveness while others have disapproved its effectiveness (Cai, 2012; Istifci, Lomidazde, \& Demiray, 2016; Qugley, 2011, 2011; Khan, 2016). These mixed results mean that it is still inconclusive whether e-learning can be effectively used to teach the English language. More revealing is that limited studies focusing on the effectiveness of English teaching via e-learning has been investigated within the Arabic context. Informed by this gap in research, the present study examined the effectiveness of teaching English using the e-learning platform in Arab universities in the Arab world.

\section{Research Questions}

This study responded to the following research questions

- What are the tools that facilitate the learning of English Language via e-learning platform?

- What are the shortcomings and benefits of e-learning as a platform for teaching English language among university students in the Arab world

- What is the effectiveness of e-learning as a mode of teaching English language in the Arab universities?

\section{Research Objectives}

The study was guided by the following research objectives:

- To examine the tools that facilitate the learning of English Language via e-learning platform

- To determine the shortcomings and benefits of using e-learning as a platform for teaching English language among university students in the Arab

- To investigate the effectiveness of e-learning as a mode of teaching English language in the Arab universities 


\section{Research Aim}

This study aimed at investigating the effectiveness of e-learning as a platform for teaching English language in the Arab universities

\section{Literature Review}

\section{E-learning tools that facilitate learning language}

Today, several tools exist for use by online learners. These tools are broadly categorized into nine: photo-editing (Pixir), audio recording and editing, clear's rich internet applications (multimedia projects), videoconferencing (skype), video-production, vocabulary learning, presentation (Prezi), wordreference (collaborative working and dictionaries), editing (Amara), e-portfolios (weebly) and websites (Yale Center for Language, 2015). Other online tools were listed and grouped into twelve categories by Jeong-Bae Son (2014) as communication content/learning management systems; live and virtual worlds; Web exercise creation; Website creation; resource sharing; wikis and blogs; dictionaries and concordancers; Web search engines; and utilities (Figure 1).

These tools have been identified as facilitators of e-learning. They are believed to contribute to the effectiveness of e-learning.

For example, Lee et al. (2003) argued that Web-based instruction (WBI) programs improve oral proficiency and com- municative skills by exposing learners to a realistic language learning environment and make the learning of language more lively and interactive. As acknowledged by Lee et al. (2003) a language learning program facilitated by WBI offers practice in speaking, listening, reading and writing skills.

Lee et al. (2005) reviewed literature on learning language through the online system and noted that, as suggested in the situated learning theory, the online learning environment should: (a) provide authentic activities within context; (b) provide multiple points of views and abundant information; (c) benchmark experts' performance and thinking; (d) provide cooperative construction of knowledge; (e) offers the opportunity for practical reflection; and (f) facilitate coaching and allow for clarification of thinking. Other researchers (Lee et al., 2005; Beauvios, 1997; Pelletieri, 2000; Chun, \& Plass, 2000) have indicated that computer-mediated communication $(\mathrm{CMC})$ and WBI provides authentic language learning environment for e-learners. According to Chun, and Plass (2000), CMC and WBI provide an environment that increases motivation, social interaction and collaborative learning for learners learning via e-learning mode. Sullivan and Pratt (1996) revealed that CMC tends to impact on learners' writing proficiency and that is better than the classroom mode. Similarly, Lee et al. (2005), and Lee and Pyo (2003) revealed that writing abilities of learners improved in classes involving the use of WBI than in traditional classroom mode.

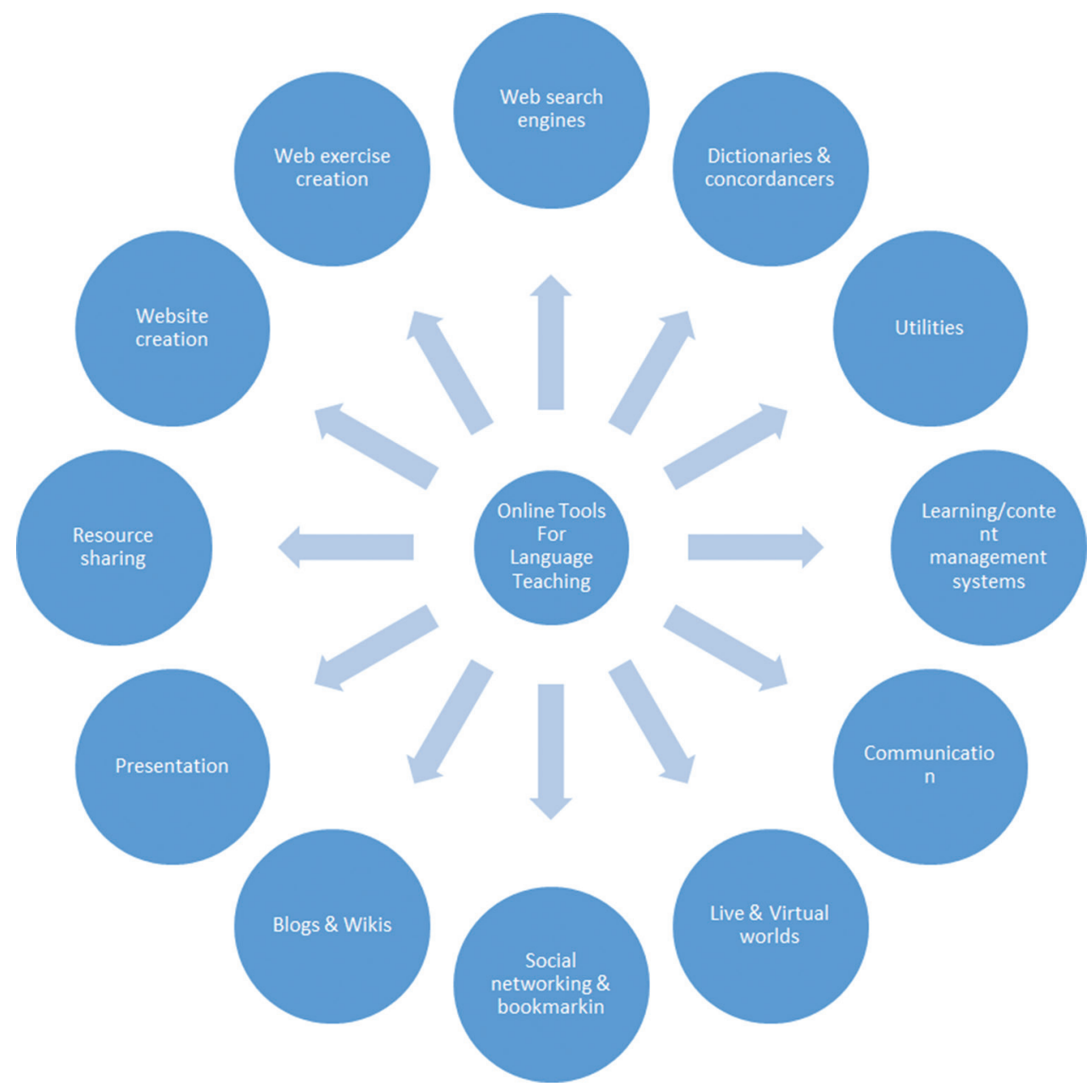

Figure 1. Categories of language learning tools for e-learning 


\section{Why Universities Embrace E-learning}

Various reasons have been identified by different researchers and documented in the extant literature as compelling universities to embrace e-learning (Rosenbaum, 2001; Kamal \& Eid, 2004; Katuk, \& Ali, 2008; Mangan, 2001; Smith, 2001; Westberry, 2009; George-Palilonis, \& Filak, 2009; McCombs \& Vakili, 2005; Hartnett, George, \& Dron, 2011).

Kamal and Eid (2004) identified advantages of e-learning: easy to monitor e-course than traditional classrooms; allows online learners to utilize electronic mails to communicate with faculty members, and it offers a cost-saving advantage to learners.

Cai (2012) investigated the use and merits of using e-learning platform to teach English. Merits of e-learning English via e-learning platform were identified as the ease of access to information, boosting learners', improvement learners' comprehension skills, and enabling students to master English. It was further noted that pedagogy strategy that focuses on e-learning's strengths might yield many rewards to the students.

Qugley (2011) sought to develop a model that offers support to teachers who tend to show reluctance in implementing the e-learning platform and assessing the effectiveness of e-learning as a learning platform for English in Thailand. It was revealed that e-Learning mode helps meet the diversity of teachers and students. Qugley (2011) further examined the obstacles to the implementation of e-learning. Obstacles were identified as scant internet resources, limited awareness of using e-learning platform, and limited resources to facilitate e-learning.

Katuk and Ali (2008) identified the associated advantages of e-learning as accessibility; flexibility; and convenience. They noted that it is less expensive to access content via e-learning platform than in the traditional classroom system. It was further indicated that e-learning results in more enriching and engaging learning experiences by promoting collaborative learning.

For Hjeltness et al. (2004) advantages of e-learning include cost effectiveness; cost efficiency, easiness of learning; long life education; saving on the part of the student and teacher; less geographical barriers; greater flexibility; and better administration.

In a similar study, González (2010) suggested that e-learners provide information to learners; offer occasional communication among learners; support knowledge building tasks, and engage learners via the online discussions.

Other researchers (e.g., Rosenbaum, 2001; Mangan, 2001; Smith, 2001) hinted that e-learning mode is more interactive than the traditional classroom mode. According to Smith (2001) e-learning makes education to be easier for slow learners as these learners require more response time in order to participate.

In view of Westberry (2009), the associated benefits of e-learning include fostering learner reflection; supporting higher levels cognition; levelling the playing field for learners; and fostering information processing. Others (e.g., George-Palilonis, \& Filak, 2009; McCombs \& Vakili, 2005) identified reasons that compel many universities to embrace e-learning. First, e-learning platform provides a consumer-centric approach to knowledge delivery, and this allows leaners greater control of their learning process. Secondly, online technologies and digital learning tend to stimulate rich interactive and highly simulative experiences for learners. Third, e-learning can be broadened and allow many students to learn within physical boundaries like classrooms. E-learning is also considered appropriate in meeting the needs the needs of the complex and changing world.

Hartnett, George, and Dron (2011) see online learning as affording several benefits to learners. First, e-learning is thought to help students overcome spatial and temporal restrictions that characterize the traditional education settings. Second, e-learning offers learners the freedom of constraints, including freedom of space, access, medium, and relationship development.

Elsewhere, O'Donoghue and Groves (2009) opined that the e-learning several benefits: (1) the ease of adaptability to a variety of learning techniques; (2) being learner centred; (3) offering pressure-free zone that allows learners to be in charge and learn at a comfortable pace; (4) easily personalized by learners and can be tailored to meet learners' needs; (5) affordable; (6) productive; and (7) mobile and global.

Reinforcing the view that increased adoption of e-learning in Middle East universities is informed by its associated advantages, Means et al. (2010) emphasized that e-learning allows the sharing of ideas; enables learner-centred teaching approaches; allows for instructor accessibility; adds pedagogical benefits; facilitates $24 / 7$ accessibility to learning/ course materials; and helpful for instructors. These results have been supported empirically by Alasraj, and Alharbi (2014). In a comparative study, Alasraj, and Alharbi (2014) reviewed the literature on the associated benefits of e-learning compared to the traditional classroom learning platform. Results revealed that learners under the e-learning platform tend to outperform their peers learning under the traditional classroom platform and that e-learning adds pedagogical benefits to the traditional classroom learning platform.

\section{Shortcomings of e-learning}

Despite the overwhelming support for the adoption of the e-learning system, barriers to its adoption by institutions of higher learning have been identified and reported to be affecting its rate of adoption and effectiveness. For example, Jenkinson (2009) identified the following as barriers to the adoption of e-learning: costly to produce; new skills required; unaffordability; and minimal social interaction.

\section{Effectiveness of e-learning}

Results of this studies are supported by those of comparative studies that assessed the effectiveness of e-learning or online learning against conventional learning (traditional forms of learning) within the Arabic context as well as in other contexts (John, Aragon, Shaik, \& Palma-Rivas, 2000; Carr-Chellman, 2006; Emerson \& Mackay, 2011; Hughes, McLeod, Brwon, Maeda, \& Choi, 2007; Maltby \& White, 2000; Emerson \& Mackay, 2011). These studies found the significant difference in students' outcomes between the traditional and e-learning approaches. In Highes et al. (2007) 
and Emerson and Mackay (2011), online students outperformed their counterparts in the face-to-face classes. In the study by Maltby and White (2000), students preferred the face-to-face classes over the online learning platform on the grounds that lectures had better educational value compared to the online system. However, a majority of students, as well as high achievers, identified the benefit of online lectures as the easy of assimilating difficult concepts. In another study involving students enrolled in 25 online courses, Ramage (2000) showed that faculty members considered online course delivery to be more effective than the traditional courses. However, these members expressed concerns over the inability of the online program to facilitate the encouragement and promotion of student interactions.

Similarly, other studies revealed that sometimes learners' outcomes tend to be slightly higher when learning using online platform than traditional classroom mode (Hubbard, 2000; Johnson et al., 2000; Ramage, 2002; Carr-Chellman, 2006; Iverson, Colky \& Cyboran, 2005; Suanpan \& Petocz, 2006). Colky and Cyboran (2005) and Suanpan and Petocz (2006) examined the effectiveness of e-learning by observing students' outcomes. The outcomes of course and grade evaluation of students revealed that outcomes for students that studied under the online platform were better than those who studied under the traditional classroom mode. These two studies demonstrated that students under the online platform had superior learning outcomes based on their level of utility and satisfaction, grades, as well as the attention to transfer learning.

Others studies have also demonstrated the effectiveness of e-learning against the traditional face-to-face classroom system.

Khan (2016) investigated the effective of teaching English via the e-learning mode. Khan also investigated the utilization of e-training for teachers; the utilization of e-resources; and the relevance of e-learning within the Saudi context. Results confirmed that e-learning was effective in teaching English. It was noted that online resources attract the attention of learners, including passive learners.

Al-Magtri (2014) investigated the use of e-learning platform by English tutors in Saudi Arabia's King Khalid University. Results revealed that both female and male teachers see e-learning as effective. However, female and male students see e-learning as ineffective. Female students were more positive towards e-learning than male students. It was noted that students were not motivated to learn through e-leaning platform citing the lack of access to the internet as the key barrier.

Facharzt et al. (2013) compared blended learning, which involved a combination of e-learning and the face-to-face learning mode, to face-to-face learning mode among medical students taking the English for Specific Purpose course in a Saudi college. The aim was to evaluate the effectiveness of blended leaning compared to the traditional classroom system. A total of 120 students were randomly categorized into two: traditional approach group and blended learning group. Blended learning was found to be statistically significantly better in all domains of education as well in written, case scenarios, and objective structured clinical examinations.

Alshehab (2013) investigated the impact of e-learning methods and the internet on the learners' ability to translate from English to Arabic within the Jordan context. A sample consisted of 40 students from Irbid National University in Jordan categorized into two: control and experimental group. The experimental group had statistically higher ability to translate between English and Arabic than the control group.

Alasraj (2014) compared the effectiveness of traditional classroom-based approaches and blended learning strategies in learning Arabic within the Saudi context. Results revealed significant differences in the learning outcomes between the two methods in favor of blended learning approach. It was noted that blended learning was more effective than the traditional classroom mode when it comes to impacting knowledge in students and that blended learning can enhance teaching.

Al-Abdullatif (2011) investigated the effectiveness of e-learning learning environment within the context of Saudi Tertiary Setting. Results revealed that e-learning platform has the potential to enhance educational outcomes and quality and optimize teaching practices. It was concluded that e-learning platform could potentially provide an excellent teaching and learning experiences in higher education.

\section{METHODOLOGY}

\section{Data Collection Tool}

Data was collected using a structured questionnaire over a three weeks period. The questionnaires were designed so that responses to questions cold be scored and score analysed and summed to obtain the measure of the respondents' opinions and attitudes towards e-learning. They permitted anonymity of respondents, and proved useful where interviews could not be used effectively to gauge the effectiveness of e-learning. All questions were written in English since participants were Arabic English speakers enrolled in English classes. Accordingly, questions contained in the questionnaire were only closed-ended. These questions focused on participants, views, opinions and attitudes. They constricted participants to a range of options making it easier for the researcher to compare answers from different respondents as well as to statistically analyse those responses. Close-ended questions allowed respondents to provide responses based on the 5 -point Likert scale. The scale ranged from 1 to 5 with 1 denoting strongly disagree and 5 denoting strongly agree.

The questionnaire consisted of two sections: Part A and Part B. Section A covered participants' demographics notably, their university, district, location whether urban or rural, their gender, and their teaching experience. Section B focused on e-learning and the students' views regarding the effectiveness of e-learning. These questions were hypothetical that is they were based on the issues documented in the extant literature with regard to effectiveness of teaching English via e-learning platform.

\section{Participants and Sample Size}

A questionnaire was sent via email to 98 Arab students in Arab universities who had enrolled for an English course. A total of 96 questionnaires were filled by participants and returned. This represented 97 percent return rate. The sam- 
ple 53 participants was considered large enough to make the results of the present study representative and generalizable to the general population.

\section{Sampling Technique}

Data was collected using convenient sampling technique. The use of this non-probability sampling technique was informed by the convenient availability of participants from which data was collected. It is identified as the most appropriate method for use to select respondents based on convenience of their availability, accessibility, or proximity. The use of this method made it easy for the researcher to sample and collect data from participants.

\section{Data Analysis}

Quantitative data was analysed using Microsoft Excel. Accordingly, participants' responses were analysed using graphs and tables.

\section{Findings}

The following key themes emerged from the results of the present study: participants' approval of e-learning for teach-

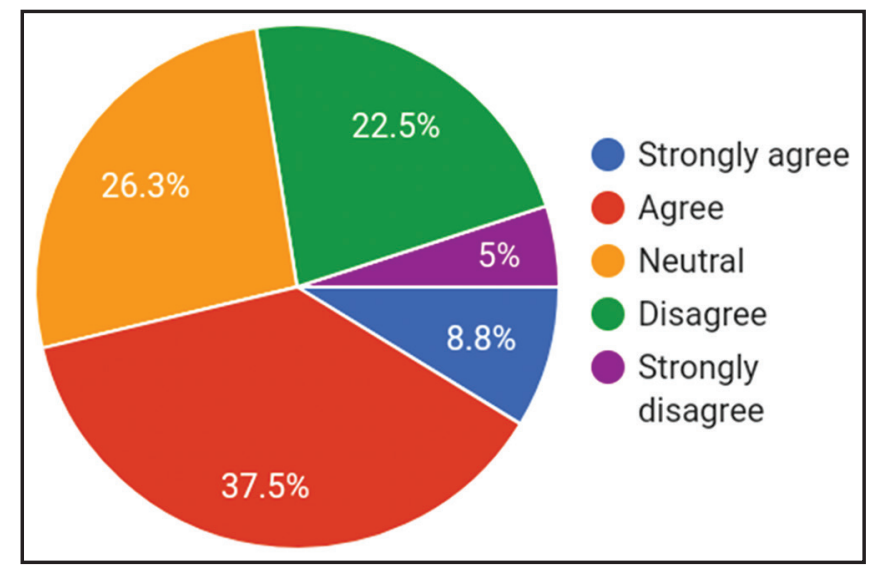

Figure 2. All English language courses should be taught through the e-learning mode

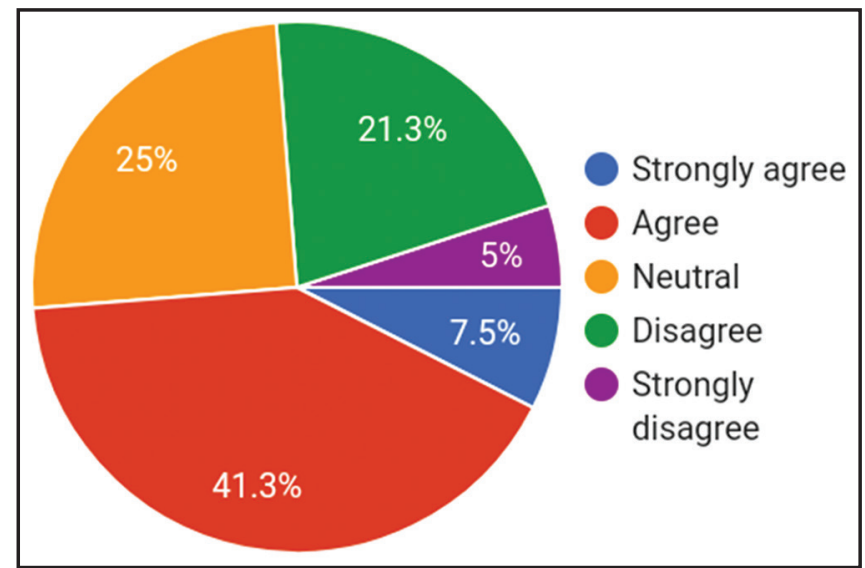

Figure 3. It is possible to learn all English language courses via the e-learning mode ing English language; usefulness and benefits of e-learning mode; shortcomings of e-learning.

\section{Approval Of E-Learning Mode For Teaching English Language}

Majority of participants (46.3) strongly agreed (8.8\%) and agreed $(37.5 \%)$ that all English language courses should be taught through the e-learning mode (figure 2).

Majority of participants (48.8\%) strongly agreed (7.5\%) and agreed $(41.3 \%)$ that it was possible to learn all English language courses via e-learning mode (figure 3 ).

Participants (56.3\%) (Agreed (40\%) and strongly agreed $(16.3 \%)$ approved the statement that e-learning was an enjoyable and interesting learning tool (figure 4).

Majority of participants (47.5\%) (agreed-35\% and strongly agreed-12.5) consented to the statement that they learn better if e-learning was used. This further confirmed their earlier approval that e-learning was an enjoyable and interesting tool for learning English language (figure 5).

It was interesting to note that majority of the participants strongly disagreed (12.5\%) and disagreed (37.5\%) to the statement that they see no difference between traditional and e-learning modes. This seemed to reinforce earlier statements that participants find e-learning to be better than the traditional classroom mode of learning (figure 6).

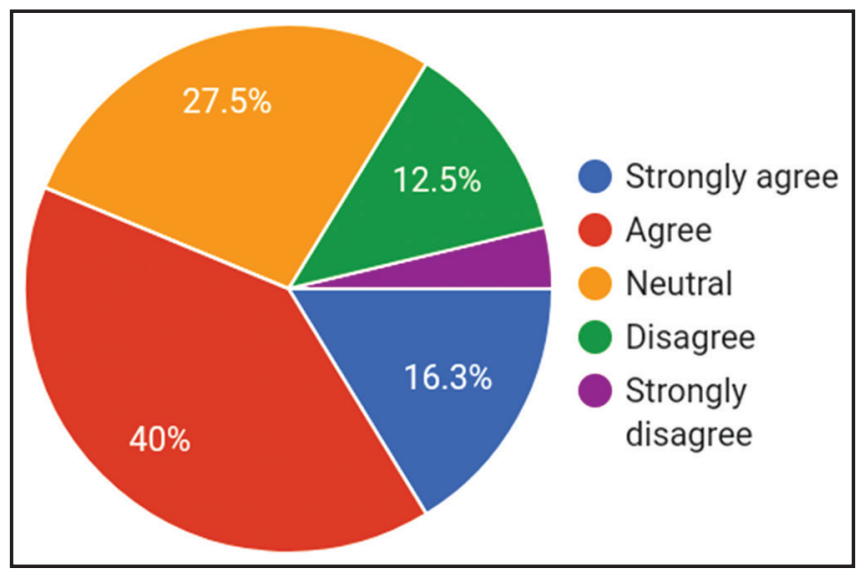

Figure 4. E-learning is enjoyable and interesting learning tool

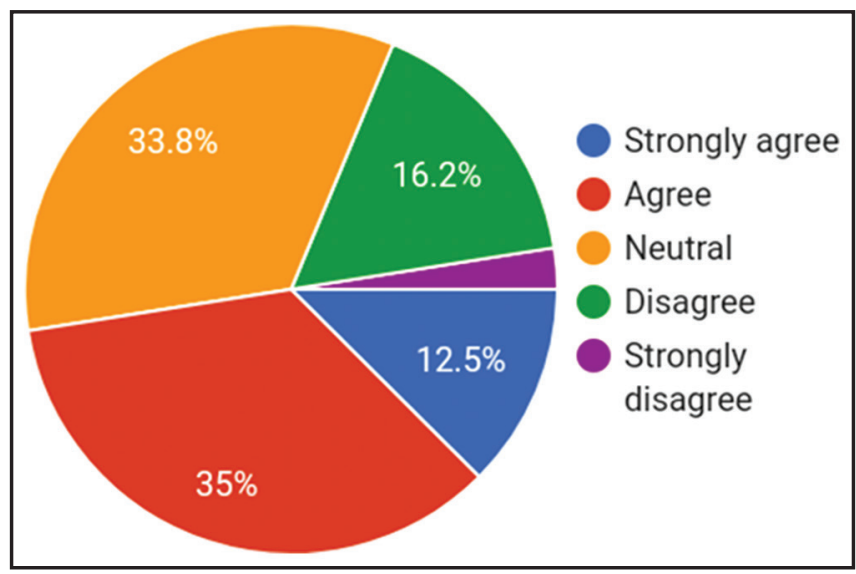

Figure 5. I lean better if e-learning is used 
Participants consistently demonstrated that e-learning was useful by strongly disagreeing (12.5\%) and disagreeing $(33.8 \%)$ to the statement that learning using e-learning was a waste of time (Figure 7).

\section{Usefulness and Benefits of E-learning mode}

Participants consistently demonstrated that e-learning was useful by strongly disagreeing $(12.5 \%)$ and disagreeing $(33.8 \%)$ to the statement that learning using e-learning was a waste of time (Figure 7).

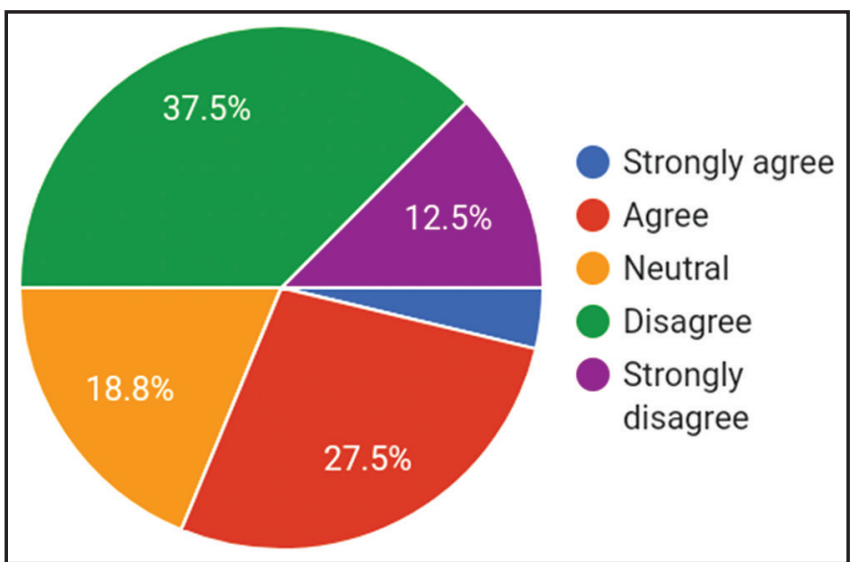

Figure 6. I see no difference between traditional and e-learning modes

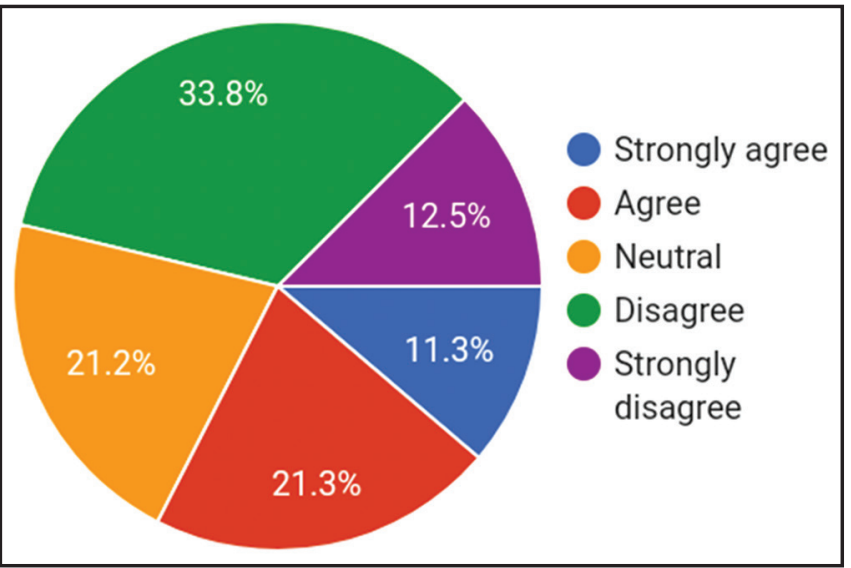

Figure 7. Learning using -learning is a waste of time

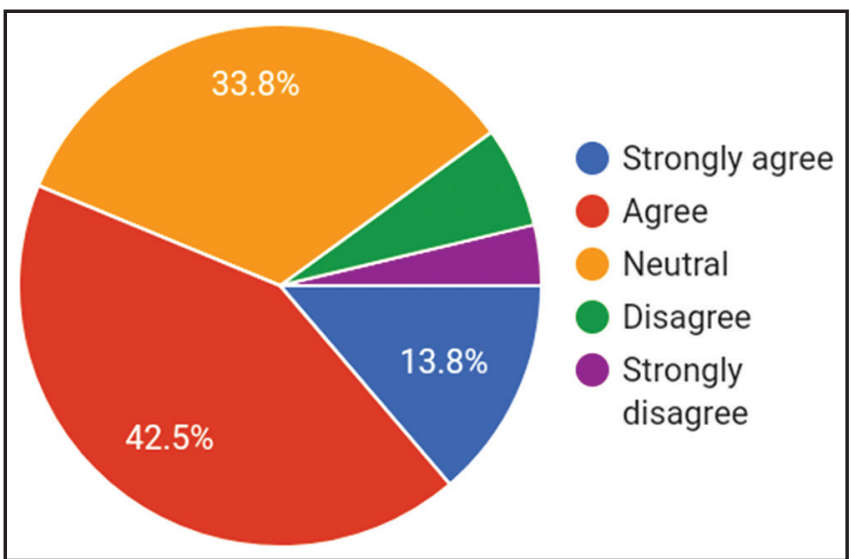

Figure 8. E-learning can be helpful in learning English in particular.

\section{E-learning as a Facilitator of Language Acquisition}

It was interesting to note that participants associate with the statement that e-learning could be useful in learning English in particular as $42.5 \%$ and $13.8 \%$ of participants agreed and strongly agreed respectively that e-learning could be useful in learning English (Figure 8).

\section{E-learning and Students' Performance}

Though a large percentage of participants $(40 \%)$ remained neutral towards the statement that their performance in English would be better through the e-learning mode than the traditional learning mode, majority (43\%) (agreed-37.5\% and strongly agreed-5\%) that their performance in English would be better through the e-learning mode that the traditional classroom mode (Figure 9).

A relatively large percentage of participants (38.7\%) were neutral towards the statement that e-learning was a better means of developing listening skills. However, only $17.5 \%$ did not agree (disagreed-11.3\% and strongly disagreed-6.2\%) with the statement. On the contrary, cumulatively $43.8 \%$ were in agreement with the statement (agreed-30\% and strongly agreed-13.8\%) that e-learning was a better means for developing listening skills (Figure 10).

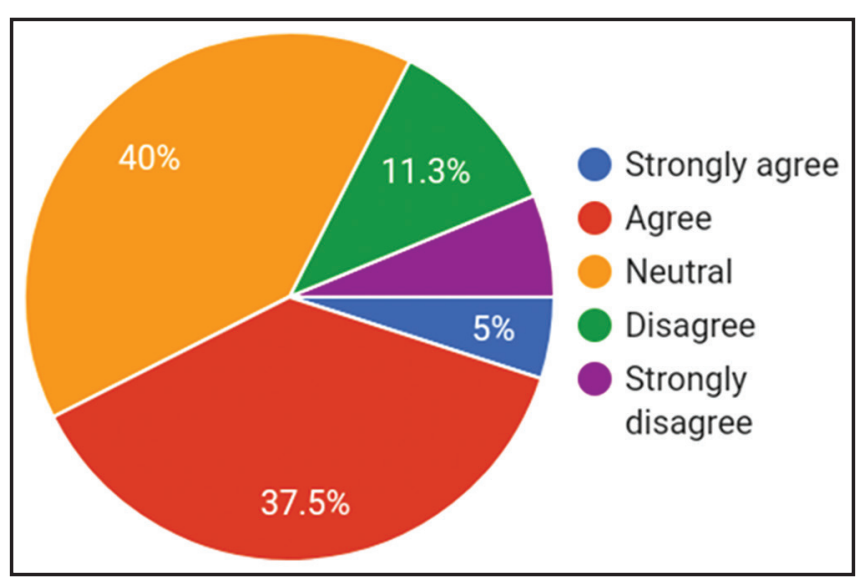

Figure 9. My performance in English would be better through the e-learning mode than the traditional classroom mode

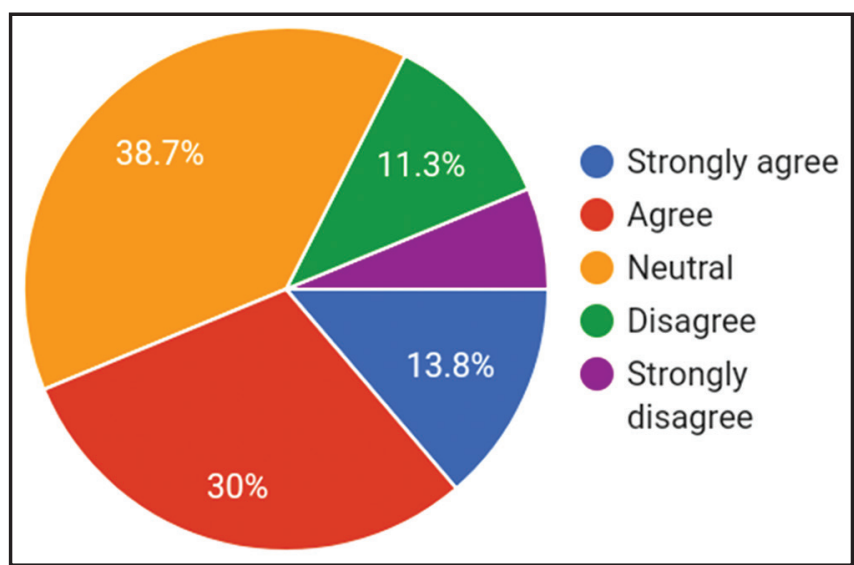

Figure 10. E-learning is better means for developing listening skills 
Similarly, a relatively large percentage of participants (37.5\%) were neutral towards the statement that e-learning was a better means of developing speaking skills. However, only $21.2 \%$ did not agree (disagreed- $12.5 \%$ and strongly disagreed-8.8\%) with the statement. On the contrary, cumulatively $41.2 \%$ were in agreement with the statement (agreed-35\% and strongly agreed-16.2\%) that e-learning was a better means for developing speaking skills (figure 11).

Participants (46.3\%) consistently approved the statement that e-learning was better in learning writing skills with $32.5 \%$ and $13.8 \%$ agreeing and strongly agreeing respectively. However, only $23.8 \%$ (disagreed- $11.3 \%$ and 1 strongly disagreed-12.5\%) of participants agreed and strongly disagreed with the statement that e-learning was better in learning writing skills suggesting that majority find e-learning to be effecting in learning writing skills (Figure 12).

More than $50 \%$ of participants (53.8\%) (agreed- $41.3 \%$ and strongly agreed-12.5\%) were in agreement with the statement that e-learning was better means for developing reading skills. $13.7 \%$ of participants agreed and strongly disagreed (disagreed-11.3\% and strongly disagreed-2.4\%) with the statement that e-learning was a better means for developing reading skills (Figure 13).

Majority of participants (48.8\%) (agreed-43.8\% and strongly agree-5\%) were in agreement with the statement

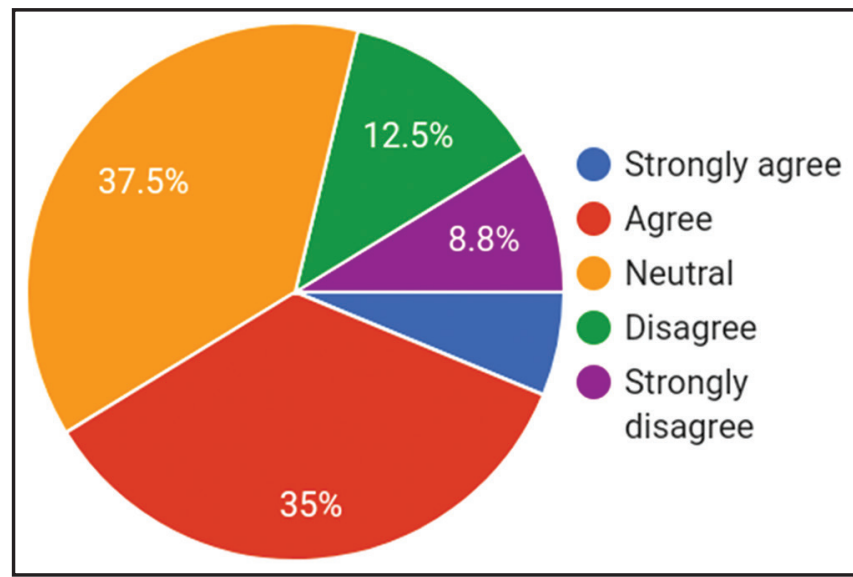

Figure 11. E-learning is a better means for developing speaking skills

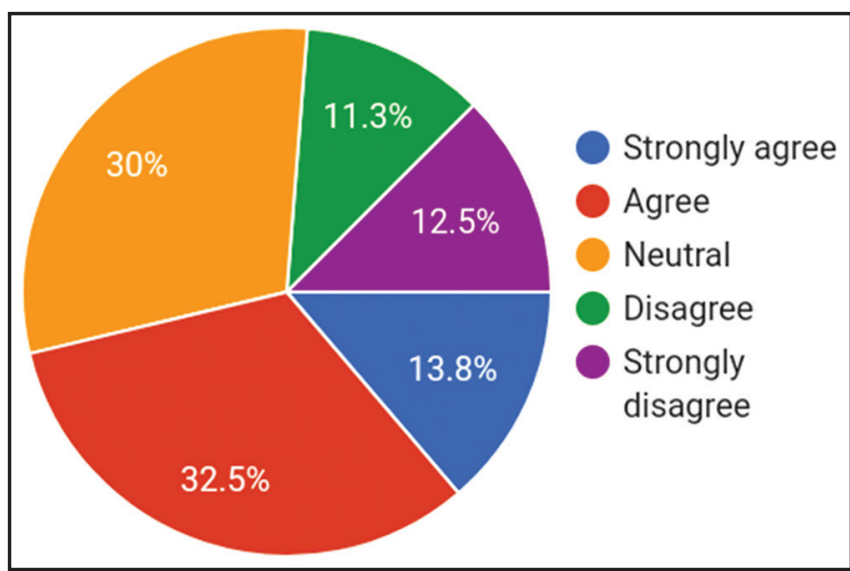

Figure 12. E-learning is a better means for developing writing skills that e-learning was better means for developing English language grammar. On the contrary, only $21.3 \%$ of participants disagreed and strongly disagreed (disagreed-13.8\% and strongly disagreed-7.5\%) with the statement that e-learning was a better means for developing English language grammar (Figure 14).

Majority of participants (48.8\%) (agreed-43.8\% and strongly agree-5\%) were in agreement with the statement that e-learning was better means for developing English language grammar. On the contrary, only $21.3 \%$ of participants disagreed and strongly disagreed (disagreed-13.8\% and strongly disagreed-7.5\%) with the statement that e-learning was a better means for acquiring English language grammar (Figure 15).

Similarly, participants overwhelmingly (62.2\%) (agreed-45\% and strongly agreed-17.5\%) confirmed their support to the statement that they preferred e-learning because it solves time commitment issues. On the contrary, only $7.5 \%$ of participants disagreed and strongly disagreed with the statement they preferred e-learning because it solves time commitment issues (Figure 16).

Participants overwhelmingly (57.6\%) (agreed-46.3\% and strongly agreed-11.3\%) confirmed their support to the statement that e-learning was a better tool for testing and evaluation. Conversely, $17.4 \%$ of participants disagreed and

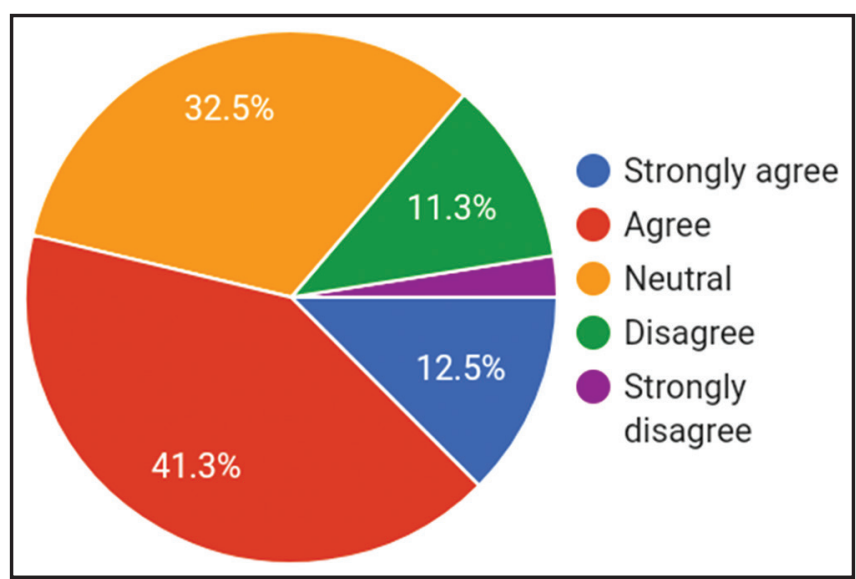

Figure 13. E-learning is a better means for developing reading skills

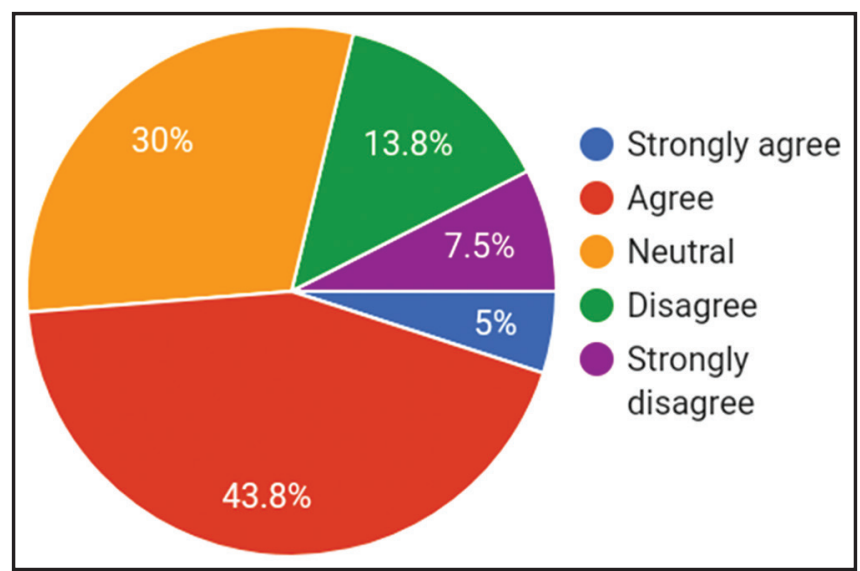

Figure 14. E-learning is a better means for developing English language grammar 
strongly disagreed with the statement that e-learning was a better tool for testing and evaluation (Figure 17).

\section{Shortcoming of E-learning}

Participants overwhelmingly (60\%) confirmed (agreed-50\% and strongly agreed-10\%) to the statement that many students lack seriousness in learning via e-learning. This may

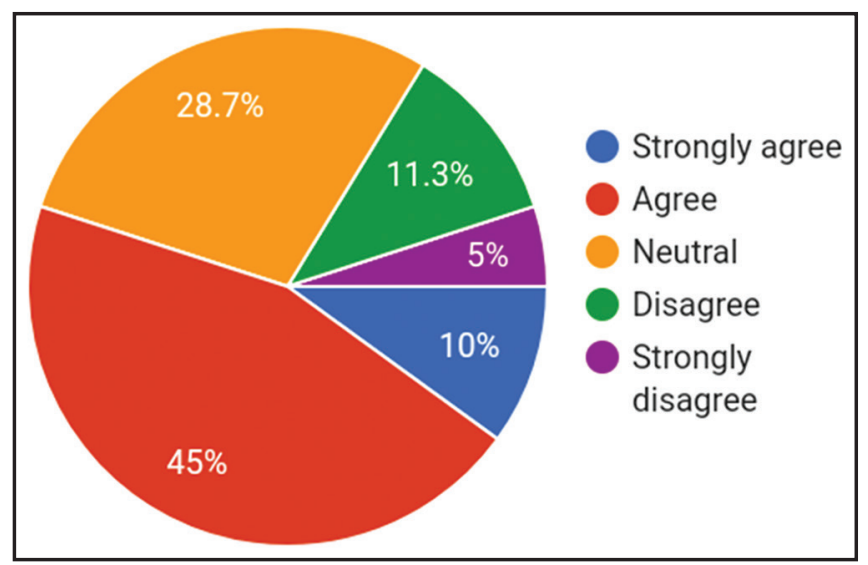

Figure 15. E-learning is a better means for acquiring vocabulary

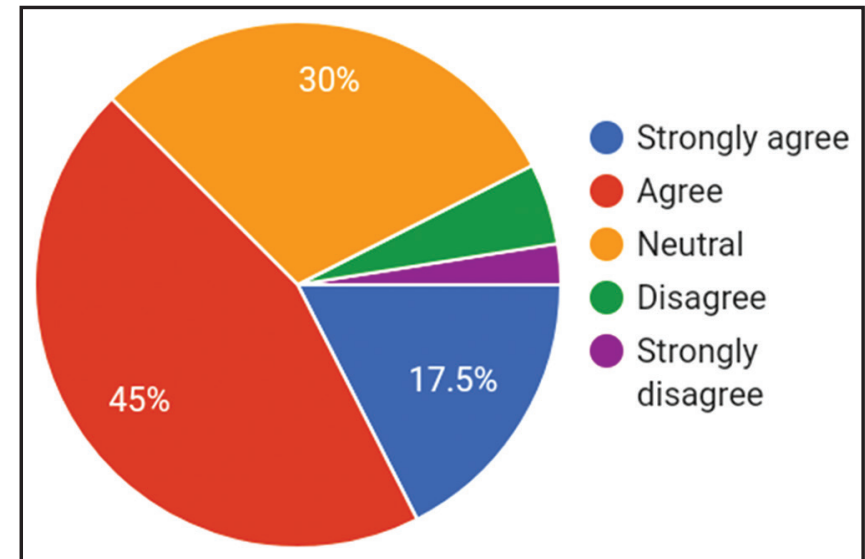

Figure 16. I prefer e-learning because it solves time commitment issues i.e. I can decide when, where and how I learn

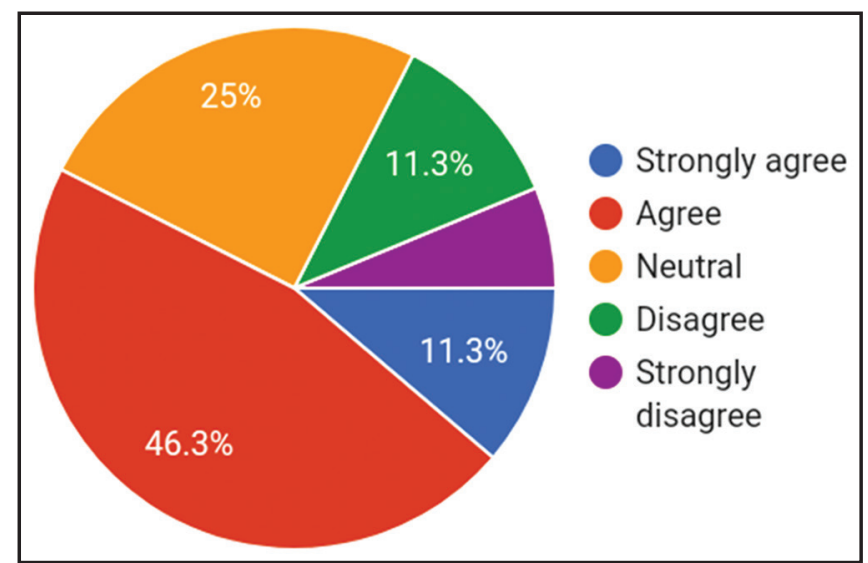

Figure 17. E-learning is a better tool for testing and evaluation have revealed the shortcoming of e-learning platform that make students not to lack seriousness (Figure 18).

Similarly, majority of participants $(46.3 \%)$ consented (38.8\%-agreed and 7.5\%-strongly agreed) to the statement that they lacked the will to study via e-learning mode. However, $35 \%$ remained neutral with regard to this statement. This highlights the shortcoming of e-learning mode as perceived by students as contributing to students' lacking the will to study via it (Figure 19).

Not surprisingly, participants overwhelmingly (70.1\%) (agreed-58.8\% and strongly agreed-16.3\%) approved the statement that e-learning was only helpful if they were serious and motivated. This confirmed that like the traditional classroom mode, the success in e-learning depends on the seriousness and motivation of the student (Figure 20). This is arguably another shortcoming of e-learning mode.

\section{DISCUSSION AND CONCLUSION}

The present study investigated the effectiveness of e-learning mode as a platform for teaching English among Arab students based on learners' opinions. Result suggested that e-learning platform is an effective platform for teaching English language. Based on the findings of this study, e-learning is an effective mode of teaching English language. It was noted that Arab learners of English in the Arab universities approve the

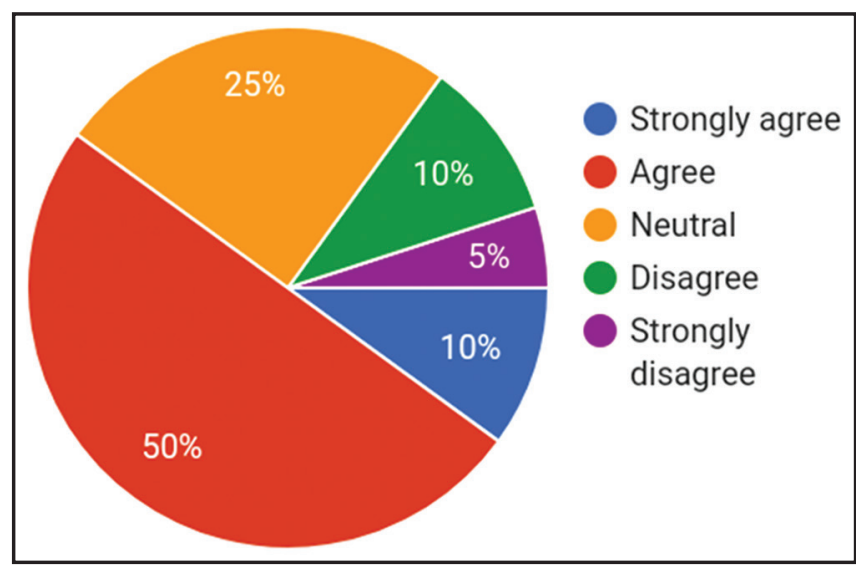

Figure 18. Many students lack seriousness in learning through e-learning

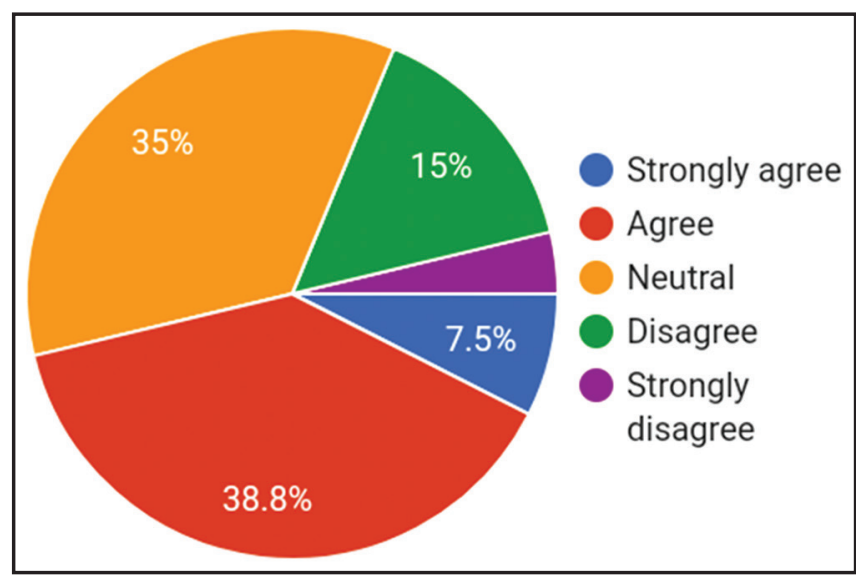

Figure 19. I lack the will to study through e-learning 


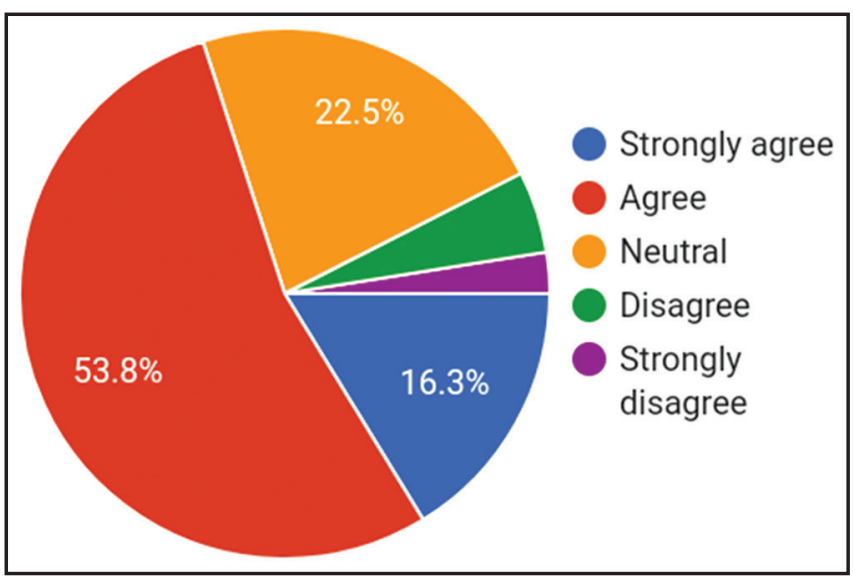

Figure 20. E-learning is only helpful if I as student is serious and motivated

use of e-learning to teach English in Arab universities. Possible benefits of using e-learning to teach English as revealed by participants include improved performance; facilitate the learning of English language; the development of listening skills; speaking skills; English language grammar; reading skills; writing skills; acquisition of vocabulary; and a tool for testing and evaluation. Participants consider e-learning platforms as a better mode of enhancing performance in English than the traditional classroom mode. Arab learners of English hold the view that e-learning is a better tool for testing and evaluation, and prefer it to other traditional methods because it solves time commitment issues and it is an interesting and enjoyable learning tool. However, as revealed in this study, e-learning has its associated shortcomings: contributes to students' lacking the will to study via it; and the successful use of e-learning largely depends on the seriousness and motivation of learners.

Results of this studies are supported by several comparative studies that assessed the effectiveness of e-learning or online learning against conventional learning (traditional forms of learning) though within not within the Arabic context (John, Aragon, Shaik, \& Palma-Rivas, 2000; Carr-Chellman, 2006; Emerson \& Mackay, 2011; Hughes, McLeod, Brwon, Maeda, \& Choi, 2007; Maltby \& White, 2000). These studies found significant difference in students' outcomes between the traditional and e-learning approaches. In Highes et al. (2007) and Emerson and Mackay (2011) online students outperformed their counterparts in the faceto-face classes. In the study by Maltby and White (2000), students preferred the face-to-face classes over the online learning platform on grounds that lectures had better educational value compared to the online system. However, majority of students as well as high achievers identified the benefit of online lectures as the easy of assimilating difficult concepts. In another study involving students enrolled in 25 online courses, Ramage (2000) showed that faculty members considered online course delivery to be more effective than the traditional courses. However, these members expressed concerns over the inability of the online program to facilitate the encouragement and promotion of student interactions.

Similarly, other studies revealed that sometimes learners' outcomes tend to be slightly higher when learning using on- line platform than traditional classroom mode (Ramage, 2002; Carr-Chellman, 2006; Iverson, Colky \& Cyboran, 2005; Suanpan \& Petocz, 2006). Suanpan and Petocz (2006) examined the effectiveness of e-learning by observing students' outcomes. The outcomes of course and grade evaluation of students revealed that outcomes for students that studied under the online platform were better than those who studied under the traditional classroom mode. These two studies demonstrated that students under the online platform had superior learning outcomes based on their level of utility and satisfaction, grades, as well as the attention to transfer learning.

There are also other studies that do not support the result of the present study. These studies found no difference in learners' learning outcomes between conventional learning mode and e-learning (Schulman, \& Smith, 1999; Russell, 1999; Motteram, 2001). For example, Russell (1999) reviewed media comparison studies, dissertations, and technical reports on students' learning outcomes. No significant difference was found between traditional and online approaches and concluded that Web-based learning does not have any advantage to the traditional approach.

Similarly, Kim (2002) assessed the effectiveness of WBI English reading course and found that the level of output-performance and collaborative learning achieved through CMC interaction did not match that of the traditional classroom learning. Kim (2002) further assessed the oral proficiency of learners using a CMC voice-communication program. The experiment involved three different instructional contexts: a CMC-only context; the context involving FFC followed by $\mathrm{CMC}$; and an FFC-only context. None of the contexts affected the measures of oral language proficiency.

\section{CONCLUSION}

The present study investigated the effectiveness of e-learning mode as a platform for teaching English among Arab students based on learners' opinions. Based on the study findings, universities in the Arab world should continue to embrace e-learning as a platform for teaching English because it is considered by learners of English as effective. It is an appropriate and better means for acquiring vocabulary, developing speaking skills, English language grammar, reading skills, writing skills, listening skill. It is also a better mode of enhancing performance, and a better tool for testing and evaluation. However, as revealed in this study, universities in the Arab world should be cognizant of the shortcomings of using e-learning as a mode of teaching English. They should find a way to overcome such shortcomings as doing so would help make the teaching of English effective. The implication of the findings of this study is that universities in the Arab world can facilitate learning of English by embracing e-learning platform.

\section{REFERENCES}

Alasraj, D. (2014). The Effectiveness of Blended Learning in Teaching Arabic as a Second Language. International Journal of Research in Humanities and Social Studies, 1(1), 13-17. 
Al-Shehri, A. M. (2010). E-learning in Saudi Arabia: 'To E or not to $\mathrm{E}$, that is the question'. Journal of family and community medicine, 17(3), 147.

Al-Abdullatif, A.M. (2011). An Investigation into the Perceptions of University Students and Instructors on the Effectiveness of Online Education in a Saudi Tertiary Environment. Doctoral Dissertation Submitted to School of Education \& Professional Studies, Arts, Education \& Law. Graffith University.

Beauvios, M. H. (1997). "Computer-mediated communication (CMC): Technology for improving speaking and writing." In M. D. Bush \& R. M. Terry (Eds.), Technology-enhanced language learning, 165-184. Lincolnwood, IL: National Textbook Company.

Cai, H. (2012). International Conference on Future Computer Supported Education

E-learning and English Teaching. IERI Procedia, 2; 841 -846.

Chun, D. M., \& Plass, J.L. (2000). "Networked multimedia environments for second language learning" In M. Warschauer \& R. Kern (Eds.), Network-based Language Teaching: Concept and Practice, 151-170.

Carr-Chellman, A. (2006). Desperate technologies: Critical Issues in e-learning and implications for higher education. Journal of Thought, 41(1), 95-119.

Emerson, L., \& Mackay, B. (2011). A comparison between paper-based and online learning in higher education. British Journal of Educational Technologies, 42(5), 727-735.

George-Palilonis, J., \& Filak, V. (2009). Blended learning in the visual communications classroom: Student reflections on a multimedia course. Electronic Journal of e-Learning, 7(3), $247-256$. Retrieved from www.ejel.org.

Ghaffari, A., \& Abbas, E. (2011). Improving education in adult through online learning. Life Science Journal, 8(3), Retrieved from http://www.lifesciencesite.com.

Hartnett, M., George, A., \& Dron, J. (2011). Examining Motivation in Online Distance Learning Environments: Complex, Multifaceted, and Situation-Dependent. International Review of Research in Open and Distance Learning, 12(6): 20-38.

Hjeltnes, T.A. \& Hansson, B. (2004).Cost efficiency and cost effectiveness in e learning.

Hughes, J.E., McLeod, S., Brown, R., Maeda, Y., \& Choi, J. (2007). Academic achievement and perceptions of the learning environment in virtual and traditional secondary mathematics classrooms. The American Journal of Distance Education, 21(4), 199-214.

Iverson, K.M., Colky, D.L., \& Cyboran, V. (2005). E-learning takes the lead: An empirical investigation of learner differences in online and classroom delivery. Performance Improvement Quarterly, 18(4), 5-18.

Johnson, S., Aragon, S., Shaik, N., Palma-Rivas, N. (2000). Comparative analysis of learner's satisfaction and learning outcomes in online and face-to-face learning environments. JI. of Interactive Learning Research, 11(1), 29-49.

Jenkinson, J. (2009). Measuring the effectiveness of educational technology: What are were attempting to measure? Electronic Journal of e-Learning, 7(3).

Jeong-Bae Son, K. (2014). Computer-Assisted Language Learning: Learners, Teachers and Tools. New York, NY: Cambridge Scholars Publishing.
Kim, S. (2002). "CMC-based interaction for collaboration in a web-based English reading course: A case study". Foreign Languages Education, 19(4), 57-91.

Khan, I.A. (2011). Effectiveness of E-learning for the Teaching of English: A Study of Comparative Strategies. $\mathrm{Ad}$ vances in Language and Literary Studies, 7(3): 30-60.

Lee, C., \& Pyo, K. (2003). "A study on the effectiveness of online/offline English language learning at university level". Multimedia-Assisted Language Learning, 6(1), 90-110.

Lee, S., Kim, J., Lee, J., \& Liu, X. (2005). “The Effectiveness of Online Situated Environments for Language Learning", Proceedings of $21^{\text {st }}$ Annual Conference on Distance Teaching and Learning, 1-4.

Maltby, J.R., \& Whittle, J. (2000). Learning programming online: Student Perceptions and Performance. Proceedings of the ASCILITE 2000 Conference. Retrieved $5^{\text {th }}$ April 2018 from http://www.ascilite.org.au/conferences/coffs00/papers/john_maltby.pdf.

Mangan, K. S. (2001). Expectations evaporate for online MBA programs. Chronicle of Higher Education, $48(6), 31$.

Means, B., Toyama, Y.R., Murphy, R., Bakia, M., \& Jones, K. (2010). Evaluation of Evidence-Based Practices in Online Learning: A Meta-Analysis and Review of Online Learning Studies. Washington: US Department of Education.

McCombs, B. L., \& Vakili, D. (2005). A learner-centered framework for e-learning. Teachers College Record, 107(8), 1582-1600. doi: 10.1111/j.1467 9620.2005.00534.x.

Motteran, G. (2001). The role of synchronous communication in fully distance education. Australian Journal of Educational Technology, 17(2), 131-149.

Pelletieri, J. (2000). "Negotiation in cyberspace: The role of chatting in the development of grammatical competence", In M. Warschaue (Ed.), Telecollaboration in Foreign Language Learning, 59-86. Honolulu, Hi: University of Hawaii. Second Language.

Qugley, D. (2011). E-Learning as a Strategy to Teach English in Thailand: A Professional Development Model to Support Teacher Growth. US-China Education Review A, 5, 624-631

Quis, Q. (---). Interoperability and Standards in e-learning. Trondheim, Norway: TISIP Research Foundation.

O’Donoghue, J., \& Groves, M.J. (2009). Reflections of Students in Their Use of Asynchronous Online Seminars. Educational Technology \& Society, 12(3), 143-149

Ramage, T.R. (2002). The "No Significant Difference" Phenomenon: A Literature Review. Ramage FINAL Retrieved from https://globalelearningjournal.files.wordpress.com/./glover-and-lewis-student-prefere

Rosenbaum, D. B. (2001). E-learning beckons busy professionals. ENR, 246(21), 38-42

Russell, T.L. (1999). The no significant difference phenomenon: A comparative research annotated bibliography on technology for distance education. North Carolina: IDEC.

Sullivan, N., \& Pratt, E. (1996). "A comparative study of two ESL writing environment: computer-assisted classroom and a traditional oral classroom", System, 24, 491-501, 
Schulman, A.H., \& Smith, R.L. (1999). Learning in an online platform versus an in-class format: An experimental study. T.H.E. Journal, 26(11), 54-56.

Smith, L. J. (2001). Content and delivery: A comparison and contrast of electronic and traditional MBA marketing planning courses. Journal of Marketing Education, 23(1), 3 .

Son, J. (2011). 'Online Tools for Language Teaching', Teaching English as a Second or Foreign Language. Available: http://www.teslej.org/wordpress/issues/volume 15/ej57/ ej57int/, [16 March 2015].
Urij, L.Z., Dmitrii, V.M., Bogdan, U.V. (2016). An effective role of e-learning technology for English Language Teaching by using meta communication actors.

Yale Centre for Language (2015). 'Online Teaching Tools and Resources'. Available: http://cls.yale.edu/online-teaching-toolsresources.

Westberry, N. C., (2009). An activity theory analysis of social epistemologies within tertiary level e-Learning environments, University of Waikato, Hamilton, New Zealand. Retrieved from http://researchcommons. waikato.ac.nz/bitstream/10289/4184/3/thesis.pdf. 